\title{
Kotły Beethovenowskie jako partytura braku
}

W dramacie Ludwiga Tiecka Der Ritter Blaubart jeden z bohaterów Simon, snując rozważania na temat możliwości i granic poznania, dochodzi do aporii: jak można ludzkim umysłem ogarnąć proces myślenia, skoro myśląc, nie można przekroczyć granic umysłu? ${ }^{1} \mathrm{~W}$ drugiej połowie XX wieku pytanie to pojawiło się znowu, w innej postaci. Grupa filozofów i badaczy literatury zaczęła zastanawiać się nad kwestią, czy można w pełni zrozumieć istotę pisania i pisać o literaturze (czyli o pisaniu), skoro do obydwu celów służy ten sam język, narzucający wszystkim swoim użytkownikom te same reguły. Tak jak nie można przyjąć pozycji zewnętrznej wobec procesu myślenia, tak nierealne jest też usytuowanie się literaturoznawstwa w metajęzyku, języku nadrzędnym i porządkującym wytwory języka literackiego sensu stricto. Rozważania te wstrząsnęły fundamentami nauk literaturoznawczych. Jacques Derrida, Roland Barthes i teoretycy skupieni wokół Szkoły Krytyków z Yale rzucili wyzwanie scjentystycznym zapędom strukturalistów oraz tradycyjnej sztuce interpretacji ${ }^{2}$. Poszukiwanie prawdy i odkrywanie

${ }^{1}$ Por. następującą refleksję dotyczącą myślenia: „Siehst du, ich denke, und mit dem Zeuge, womit ich denke, soll ich denken, wie dieses Zeug selbst beschaffen sey. Es ist pur unmöglich. Denn das, was denkt, kann nicht durch sich selbst gedacht werden.“ TiecK (1818: 50). [„Widzisz, myślę, i tym urządzeniem, którym myślę, mam myśleć o tym, jak to samo urządzenie jest skonstruowane. To po prostu niemożliwe. Ponieważ to, co myśli, nie może zostać przez siebie samo pomyślane”. Tłum. - K.S.P.].

${ }^{2}$ Rok 1966 uważany za historyczny początek poststrukturalizmu przyniósł zarówno „szczyt naukowego strukturalizmu, jak i [...] jego przesilenie - apogeum tendencji scjentystycznych $\mathrm{w}$ humanistyce przerodziło się bowiem $\mathrm{w}$ ich gwałtowne załamanie i sprowokowało niejako pojawienie się opcji krytycznej (lub mutacji) strukturalizmu" (BURZYŃSKA 2006: 16). 
właściwego sensu dzieł literackich zastąpili innym, rewolucyjnym rodzajem czytania tekstu: dekonstrukcją. Zamiast tłumaczyć, co dzięki danemu tekstowi możemy zrozumieć, zaczęli badać elementy, które jego zrozumienie uniemożliwiały. Zamiast podkreślać w dziele literackim obecność sensu, zastanawiali się nad miejscami jego nieobecności. Ukazując „punkty oporu” tekstów, uniemożliwiające całościowe i jasne ujęcie znaczenia, głosili nieredukowalność écriture. Zaproponowali jako strategię czytania „namysł nad elementami, które wydają się opierać totalizacji znaczenia, i tymi, o których z początku pozornie nie ma nic do powiedzenia" (Eco/RorTy/Culler/Brooke-Rose 1996: 121). W literackiej polifonii usłyszeli nie tylko pierwsze skrzypce, ale również pozostające dotychczas w cieniu kotły.

Dekonstrukcjoniści zdawali sobie sprawę z tego, że „Nieredukowalność écriture oraz [...] obalenie logocentryzmu lepiej niż gdzie indziej dochodzi do głosu w pewnych określonych formach praktyki literackiej” (DERRIDA 1997: 20). Tekstem jakby stworzonym, by na jego przykładzie prześledzić niektóre założenia dekonstrukcji, są Kotty Beethovenowskie Michała Choromańskiego. Cechę szczególną tego utworu stanowi niezwykle częste występowanie na płaszczyźnie narracyjnej zaczerpniętych z dziedziny muzyki wskazówek wykonawczych, opisywanie świata przedstawionego za pomocą terminów muzycznych ${ }^{3}$. Pojęcia techniczne, agogiczne i dynamiczne (jak np. con sordino, accelerando e crescendo) określają zachowanie i stany emocjonalne postaci oraz tempo akcji i atmosferę scen. O ile notacja muzyczna jest systemem znaków, które precyzyjnie wskazują dźwięki i sposób ich wykonania, o tyle w Kotłach Beethovenowskich terminy muzyczne towarzyszą znakom, które okazują się puste, niejednoznaczne lub fałszywe, odraczają obecność znaczonego wręcz ostentacyjnie. Pojęciem, które pozwala uchwycić te dwie najważniejsze właściwości tekstu Choromańskiego, muzyczność i grę nieuchwytnych znaczeń, wydaje się zatem metafora partytury braku.

${ }^{3}$ Powieść zawiera także wiele innych elementów muzycznych. Jej główny bohater Janek Fiłomadzki jest pianistą. W tekście pojawiają się nazwiska znanych i mniej znanych muzyków (Ludwig van Beethoven, Karol Szymanowski, Paul Casals, Jerzy Żurawlew), tytuły utworów instrumentalnych, operowych i baletowych. Janek niejednokrotnie rozwodzi się na temat problemów techniczno-wykonawczych związanych z grą na fortepianie. Kumulacją terminów muzycznych jest opis śmiertelnej choroby doktora Marcinkiewicza (por. CHOROMAŃski 1970: 285; dalej w artykule, lokalizując cytaty z tego utworu, posługuję się skrótem KB i numerem strony). Aspekt muzyczności Kottów Beethovenowskich omawia dogłębnie Maria WoźNIAKIEWICZ-DzIADosz (1979). 


\section{Od prowincjonalnej dziury do autorefleksyjności}

Pierwsze miejsce puste odsłania się w związku z opisem miasteczka, w którym rozgrywa się akcja powieści. W śledzonym w niniejszym artykule kontekście braku uwagę zwraca słowo „dziura”, pojawiające się dwukrotnie we wprowadzeniu do opisu: „Zawitał on do naszej prowincjonalnej dziury przed niecałym półroczem [...]. Ale przedtem dorzucę trochę szczegółów o samej dziurze, zapadłej, zapomnianej przez Boga... i zabitej deskami...” (KB 11).

„Dziura” uruchamia proces migotliwego przepływu znaczeń, charakterystyczny dla powieści. Niezależnie od tego, czy zjawisko to określimy jako Derridowską dyseminację, czy jako jeszcze strukturalistyczną polisemię, nietrudno stwierdzić, że pole semantyczne słowa „dziura” rozsiewa tu różne znaczenia. Pierwsze znaczenie, które wynika z kontekstu, to negatywnie zabarwione określenie małej mieściny. Przebija przez nie, zwłaszcza po dokładniejszym przyjrzeniu się tekstowi, znaczenie pierwotne słowa „dziura”, czyli brak, przerwa, pustka, nieobecność materii. „Dziura”4 kojarzy się również z czarną dziurą - obiektem astronomicznym - tworem o niesłychanej sile grawitacji, wsysającym każde ciało, które przypadkiem znajdzie się w jego zasięgu.

Powieść Kotty Beethovenowskie zawiera bardzo dokładny i obfitujący w takie szczegóły, jak nazwy ulic, opis miasteczka, w którym rozgrywa-

${ }^{4}$ Dwa inne wymiary „dziury” wskazuje w swojej pracy R. Chodźko, analizując Kotty Beethovenowskie jako przykład konfesji podmiotowej. Stwierdza on, po pierwsze, że „autor Kotłów Beethovenowskich zdaje się wyznawać przewrotną »dialektykę«: »ja« i maski-roli. [...] Maska czy maski i role w świecie przedstawionym Choromańskiego to surogat estetyki »niedostatku «, naszego »braku« (skazy, feleru, defektu) w materii osobowości” (СноDźко 1993: 132). I rzeczywiście, w powieści aż roi się od ludzkich ułomności: Marysia Falcowa, sinobroda miłość młodziutkiego Janka, „głuchnie”, zażywając chininę. Niedoskonałość ludzkiego postrzegania nie daje się wykluczyć, mimo usilnych starań bohaterów - na próżno wdowa po staroście nakazuje Fiłomadzkiemu, by sprawdził, czy ktoś ich nie podsłuchuje - kochankowie nie słyszą ani nie widzą szpiegującej ich Eriki Natowskiej. Głucha jest też ciocia Mela, była baletnica Erika Natowska kuleje, Szton określa w swojej opowieści panią Wdowiczewską jako ślepą. Na postępujący zanik słuchu cierpiał wreszcie Ludwig van Beethoven, którego IX symfonia i jej kotły stanowią istotny element powieści.

Kategorię dziury, luki odnajdujemy ponadto w przytaczanej przez R. Chodźkę opinii K. Thiele-Dohrmanna na temat powstawania plotki: „Własną niepewność człowiek stara się usunąc przy pomocy fantazjowania; plotkując wypełnia luki niewiedzy [...]" (Снорźко 1993: 113). W Kotłach Beethovenowskich ewidentnie brakuje wiadomości niezbędnych do skonstruowania logicznego przebiegu wydarzeń, co stwarza klimat pobudzający do plotek. Plotka to wiadomość przedostająca się przez „dziurkę od klucza”. I tak np. szatniarz w restauracji Pod Ratuszem nie może powstrzymać się od plotkowania na temat wydarzeń związanych ze śmiercią cioci Meli (por. KB 456). 
ją się kluczowe wydarzenia. Precyzyjnie określony zostaje również adres zamordowanej cioci Meli. Podane jest miejsce zamieszkania rodziny Fiłomadzkich przed śmiercią rodziców Janka (narratora autodiegetycznego), dowiadujemy się ponadto, że studiuje on w Warszawie w ten sposób tekst dostarcza czytelnikowi wielu wskazówek pozornie ułatwiających orientację. W rzeczywistości nagromadzone detale tuszują brak podstawowej informacji identyfikującej - nazwy własnej miasteczka. To, co istotne, pozostaje nieuchwytne. Takie zabiegi substytucyjne pojawiają się $\mathrm{w}$ powieści kilkakrotnie.

Brak, będący $\mathrm{w}$ powieści tropem namacalnym, aczkolwiek irytującym, bo prowadzącym donikąd, pojawia się również w zestawieniu $\mathrm{z}$ wierzbą przyciągającą $\mathrm{w}$ niewytłumaczalny sposób błyskawice, darzoną przez mieszkańców czcią i będącą obiektem zainteresowania tajemniczego przybysza Ludomira Sztona. Czytamy w tekście, że u podnóża gromowej wierzby leżały składane przez ludzi wota, „Natomiast sama spalona dziupla ziała pustką - na jej żałobnym tle nie było żadnego świątka. A za pustką było - co?” (KB 364-365). Pytanie o obecność za pustką to pytanie o kulisy świata, o sterujący nim absolut, a ściślej antymetafizyczna refleksja sugerująca jego utratę. Zresztą i sama wierzba znika pod koniec powieści, zostaje wycięta, czym przypieczętowana zostaje niewytłumaczalność tajemnicy.

Janek Fiłomadzki, który opowiada historię, kilkakrotnie ma poczucie, że czegoś mu brakuje, że coś zgubił. Czytelnik na próżno stara się odgadnąć związek zagubionych przedmiotów z przebiegiem wydarzeń oraz ocenić jego wagę, ale towarzyszy mu, podobnie jak autodiegetycznemu narratorowi, nieokreślone, dręczace wręcz przeświadczenie $\mathrm{o}$ istnieniu takiego związku ${ }^{5}$. Z poczuciem braku wiąże się poczucie niewytłumaczalnego chłodu, kolejny niejasny znak, którego odniesienie do zawikłanego splotu późniejszych wydarzeń pozostaje niepojęte zarówno dla narratora, jak i czytelnika. Ten rodzaj braku ma charakter absolutny, jest brakiem samym $\mathrm{w}$ sobie, oderwanym od konkretnego przedmiotu, który to przedmiot ukazuje się dopiero z opóźnieniem:

Znacznie bardziej intrygowało mnie, jeżeli nie dokuczało, ponowne uczucie, żem coś zgubił w ogródku u Sztona. Skoro nie była to cy-

${ }^{5}$ Czytelnik postępuje w swojej lekturze dokładnie tak jak Janek wewnątrz powieści. Takie powtórzenie procesów myślowych bohatera przez odbiorcę zauważył należący do kręgu dekonstrukcjonistów Hillis Miller w odniesieniu do Wichrowych Wzgórz Emily Brontë. Sugeruje on, że „narrację Lockwooda można uznać za "powtórzenie " najogólniej ujętego procesu czytania (Lockwood próbuje wyjaśnić tajemnicę Wichrowych Wzgórz i, podobnie jak czytelnik powieści, popełnia przy tym błędy nietrafnie interpretując znaki)" (BURZYŃSKA 2006: 281). 
W dzień imienin młodego pianisty przydarza mu się szczególna „zguba" - sugerowany przez obcego człowieka brak przedmiotu, który do Janka nie należy (obserwujemy tu odwrócenie naturalnego porządku rzeczy, bowiem żeby coś zgubić, trzeba to coś najpierw posiadać). Tajemniczy rowerzysta wręcza Jankowi bombonierkę, jak się potem okazuje niezawierającą czekoladek, ale wycinki z gazet, twierdząc, że Janek je zgubił:

Znowu nic nie wywnioskowałem. Nie dostrzegłem dziury, zapomniałem, że nieznajomy powiedział: - Czemuż to pan gubi rzeczy na ulicy? - wówczas gdy nic nie zgubiłem [...].

KB 257

Fragment ten dowodzi, że „dziura” wiąże się w powieści z procesem myślenia, stanowi atrybut świadomości ludzkiej, która nie jest w stanie ogarnąć wszystkiego, na próżno stara się scalać fakty w logiczny ciąg i unikać błędów. Właściwy tradycyjnej metafizyce ogląd zjawisk okazuje się złudzeniem:

Ale mózg mój pracował już wadliwie. Jak to się potem pokaże - skłonny był do gorączkowych nonsensów. Niekiedy nie wnioskowałem nic, niekiedy zaś dochodziłem do zgoła błędnych, przesadnych wniosków. W czasie takiego zamętu sprawność logiczna zawodzi. Pozostaje jej namiastka. Jakaś logiczna karykatura. Przyzwyczajeni do logicznego myślenia, zachowujemy nadal nawyk do logiki, tylko że jest ona wówczas dziwnie dziurawa. My zaś w popłochu nie dostrzegamy tych dziur.

KB 256-257

Wszystko to było bez sensu i pełno w mym rozumowaniu było dziur.

KB 263

Przywołane uwagi Janka mają charakter zdecydowanie autorefleksyjny nie tylko w odniesieniu do myślenia o sposobie myślenia, ale też w sensie rozważań o powstawaniu, charakterze i recepcji literackiej narracji. Ponieważ Janek jest narratorem pierwszoosobowym, jest zatem tym, kto (oczywiście w ramach świata przedstawionego) opowiadając, próbuje porządkować rzeczywistość, o której opowiada. Fakt, że w jego rozumowaniu „pełno dziur”, sceptycznie nastawia czytelnika do wiarygodności jego relacji. Odbiorca przyzwyczajony do tradycyjnej prozy 
prawdopodobnie mimo to będzie usiłował wyodrębnić z opowiadania Janka koherentny ciąg przyczynowo-skutkowy, uciekając się do ,gorączkowych nonsensów" - zabiegów interpretacyjnych, które prowadzą do „błędnych i przesadnych wniosków” - nadinterpretacji. Zamęt wirujących w powieści signifiant i signifié stawia duży opór konwencjonalnym sposobom odbioru tekstu, zezwala jedynie na ich „namiastkę”. Jakikolwiek wątek aktywowany w Kottach Beethovenowskich próbowalibyśmy śledzić, dążąc do logicznego rozwiązania - kryminalny, szpiegowski, antysemicki, erotyczny - musimy nieuchronnie dojść do punktu, w którym się on urywa. Pozostaje „dziura”. Ale tekst eksponuje swoje „dziury” w sposób tak wyraźny, że trzeba działać w wielkim „popłochu”, żeby ich nie zauważyć. Demonstruje w ten sposób sprzeciw wobec teoretycznych uogólnień i spójnych interpretacji, niezależnie od tego, czy ich przedmiotem jest rzeczywistość, czy literatura.

\section{Zbrodnia, której nie było?}

„Brak” cechuje życiorys Janka Fiłomadzkiego. Janek jest sierotą, jego rodzice zginęli $\mathrm{w}$ wypadku samochodowym. Powstałe po ich śmierci puste miejsce zajmuje ciotka, zastępując chłopcu rodziców. Zamordowana ciocia Mela okazuje się zresztą substytutem podwójnym. W Kotłach Beethovenowskich narracja skonstruowana jest według reguły medias in res, zaczyna się więc od sceny odkrycia zbrodni ${ }^{6}$ i cofa się następnie do wydarzeń ją poprzedzających (przeskakując zresztą w czasie jeszcze kilkakrotnie). Kotty Beethovenowskie - partytura braku - rozpoczynaja się, jak wiele innych powieści kryminalnych, punktem zdawałoby się kulminacyjnym - znalezieniem ofiary. Motyw cioci Meli zostaje jednak po kilku stronach zdemaskowany jako substytut właściwego centrum narracji - nieobecnego w „anteludium” (KB 367) Ludomira Sebastiana Sztona - odwlekający jego pojawienie się w tekście:

Historia niniejsza nie jest zadedykowana nieszczęściu, jakie spotkało moją ciocię - ciocię, której z całego serca nienawidziłem. Jestem i pozostanę do końca najzupełniej szczerym. O ciocię Melę tu nie idzię7.

${ }^{6}$ Taka konstrukcja jest charakterystyczna dla modelu powieści detektywistycznej. Seweryna Wysłouch podkreśla występowanie w Kottach Beethovenowskich klasycznego dla tego gatunku literackiego układu elementów: „Zaraz na wstępie mamy więc 3 niezbędne elementy powieści kryminalnej: ofiarę, podejrzanego i rzecznika prawa, który ma rozwikłać zagadkę" (WysŁouch 1977: 151).

${ }^{7}$ Dokładnie to miejsce cytuje również Seweryna Wysłouch. Nie uważa ona jednak, że posłużenie się przez Choromańskiego zabiegiem substytucyjnym wskazuje na rozwój tekstu ukierunkowany na przekór powieści kryminalnej, wręcz przeciwnie, traktuje ona 
W chwili popełnienia kluczowego dla akcji powieści morderstwa, Szton wyjeżdża z miasteczka, zasiawszy niepokój wśród mieszkańców. Jego nieobecność jest jednak po Derridowsku obecna - zostawia swe ślady w znakach i w niewytłumaczalny sposób wpływa na kolejne zdarzenia.

Informacje związane $\mathrm{z}$ morderstwem są od początku nieścisłe. $\mathrm{Na}$ płaszczyźnie językowej pojawiają się „dziury”, opóźniając moment rozpoznania znaczenia słów i odsyłając do innych znaków. W wieczór popełnienia zbrodni Janek biegnie po pomoc do swojego sąsiada, fotografa Grubowolskiego, krzycząc, że ciocia Mela „leży w kałuży... w kałuży czegoś... czerwonego!" (KB 6). Słowa te wypowiada dwa razy. W pierwszym przypadku narrator sam komentuje brak słowa „krew” we własnej wypowiedzi i wprowadzenie jego substytutu - „kałuży czegoś... czerwonego". Brak i substytut spowodowane są strachem. W drugim przypadku narrator posługuje się jedynie substytutem, nie wyjaśniając go ponownie. Znak „czerwony” kryje zatem w sobie ślad znaku „krew”, jednocześnie go wypierając, pulsując napięciem i niepokojem.

W momencie kiedy Jan Fiłomadzki wraz z sąsiadem Grubowolskim spotykają sędziego śledczego Uxakowskiego koło domu zamordowanej cioci Meli, w tekście występuje substytut tematyczny. W chwilę po wykryciu zbrodni Janek (główny podejrzany!) i sędzia rozmawiają o chorym palcu niedoszłego pianisty, pomijając fakt popełnienia morderstwa, chociaż wydawałoby się, że w takim momencie o niczym innym mówić nie można. Mimo połączonego ze zdziwieniem stwierdzenia „niezależnym płatem swego mózgu" (KB 9), że w rozmowie brak tematu zasadniczego i krąży ona wokół substytutu, narrator autodiegetyczny Janek Fiłomadzki kontynuuje wątek palca. Motyw istotny zostaje więc świadomie zepchnięty na margines. Jest to kolejny element łączący powieść z filozofią Derridy, która, jak wiadomo, kieruje uwagę czytelnika właśnie na wątki drugorzędne, traktowane dotychczas po macoszemu. Dodatkowo zastanawia, że Janek Fiłomadzki odczuwa w palcu ból, który, jak wykazało zdjęcie rentgenowskie, nie ma przyczyny. W ten sposób tekst akcentuje kategorię braku po raz kolejny.

ten fragment jako podkreślenie schematu typowego dla gatunku: „Wszystko dzieje się więc zgodnie z powieścią detektywistyczną, w której ofiara ma znaczenie o tyle, o ile wprawia w ruch sieć domysłów i poszukiwań" (WysŁouch 1977: 151). Taką interpretację uważam jednak za redukcję ważnego znaku, który już na wstępie sugeruje nieoczekiwany zwrot $\mathrm{w}$ powieści - miejsce puste $\mathrm{w}$ postaci usunięcia z niej zbrodni, dokumentujące dopiero, do jakiego stopnia tu o ciocię Melę „nie idzie” (KB 11). 


\section{Aufsätze/Artykuły}

Janek Fiłomadzki, który nienawidzi swojej ciotki, utrzymuje, że w chwili popełnienia zbrodni nie było go w domu. Pomimo jego nieobecności (braku obecności) ktoś w wieczór przestępstwa gra na fortepianie ćwiczony przez niego repertuar. Mamy tu więc do czynienia z kolejnym zabiegiem substytucji w strukturze osobowej utworu: albo $\mathrm{w}$ alibi Janka otwiera się nielogiczna dziura (może nie był w pociągu w momencie popełnienia zbrodni, jak utrzymuje, i zdemaskował się, grając na fortepianie - bohater stosuje zatem kłamstwo jako substytut prawdy), albo morderca podszywa się pod osobę Janka, wykorzystuje Janka jako swój substytut w celu uniknięcia kary i sprytnie kieruje na niego poszlaki.

„Brak” okazuje się mieć kluczowe znaczenie dla śledztwa w sprawie zamordowania cioci Meli. Sędzia Uxakowski znajduje w błękitnym pokoju metalowe pudło, które wyróżnia się spośród innych znajdujących się tam przedmiotów właśnie brakiem - brakiem odcisków palców:

Przecie zdawałoby się na chłopski rozum, że to obecność odcisków jest dowodem czegoś, nie zaś ich brak. Nie słyszałem nigdy, aby można było oskarżyć kogoś na podstawie braku śladów...

Sędzia Uxakowski stawia tym samym tradycyjne i - zdawałoby się logiczne metody śledcze dosłownie na głowie, jego postępowanie można porównać z rewolucyjnym przewrotem dekonstrukcjonistów, którzy wstrząsnęli światem literaturoznawczym, przechodząc obojętnie wobec tego, co w tekstach jest napisane, do tego, co napisane nie jest, ale w nich „pasożytuje”. To, co „na chłopski rozum” wydaje się nie do przyjęcia, stało się w okresie postmodernizmu zadaniem literaturoznawców, które Jonathan Culler opisuje jako stawianie zdrowego rozsądku pod znakiem zapytania ${ }^{8}$.

Sensacyjne w kontekście braku jest narzucające się pod koniec powieści odkrycie, że brak tu nie tylko sprawcy zbrodni, ale również może nie było i samej zbrodni ${ }^{9}$ (chociaż znalezienie ciała cioci Meli zosta-

${ }^{8}$ Por. $\mathrm{w}$ tym kontekście sformułowanie Cullera: „The main effect of theory is the disputing of »common sense «: common-sense views about meaning, writing, literature, experience” (CULler 1997: 4). [„Głównym efektem teorii jest dyskusja na temat "potocznego sensu «, opartych na "potocznym sensie « poglądów na temat znaczenia, pisania, literatury, doświadczenia”. Tłum. - K.S.P.].

${ }^{9}$ Do tego wniosku dochodzą również inni badacze, jak np. Seweryna Wysłouch: „Autor zakpił z modelu powieści detektywistycznej, kwestionując jej podstawowe zasady: konieczność racjonalnego rozwiązania zagadki i ukarania winnych" (WysŁouch 1977: 152). Zwraca ona też uwagę, znowu bez odwoływania się do konwencji dekonstrukcjonistycznej, że nietypowe rozwiązania zastosowane przez Choromańskiego sta- 
Sprawa zabójstwa cioci Meli kończy się aresztowaniem Janka (przekazanym czytelnikowi z wieloma szczegółami, łącznie z uwagą oficera, aby niedoszły pianista uważał na palce przy wsiadaniu do policyjnego $\left.w_{0 z u}^{10}\right)$. Bohater powieści wyraźnie odwołuje się do swego pobytu w więzieniu, „ciupie babilońskiej” (KB 428), skąd został podobno przekazany $\mathrm{w}$ inne miejsce, bliżej nieokreślone. Ale Choromański nie pozwala czytelnikowi wierzyć $\mathrm{w}$ żaden rzucony przekornie $\mathrm{w}$ powieści ślad. Narrator porusza się ruchem konika szachowego, skacząc z możliwości na możliwość, ukazuje jeden wariant, natychmiast go niwelując. Zabiegi takie pojawiały się w utworze od początku, lecz gęstnieją wyraźnie pod koniec powieści. Zamiast tradycyjnego rozwiązania tekst Kotłów Beethovenowskich oferuje czytelnikowi obszerną listę pytań. Spotkany przypadkowo po wyjściu Janka „z gmachu na wolne powietrze" (KB 429) Grubowolski udaje (lub nie udaje?), że nie wie, co działo się z Fiłomadzkim podczas jego nieobecności w miasteczku i jako sprawców zbrodni wskazuje znanych z mętnych interesów mieszkańców Chryjówki. Czy słowo „gmach” na pewno oznacza więzienie, czy staje się kolejnym „wejściem do gry”?

Jeżeli poszlaki prowadziły do Chryjówki, Janek byłby oczyszczony z zarzutów. Ale w rozmowie ze znajomymi, którzy potrzebni są Fiłomadzkiemu do poświadczenia pewnych faktów, łączących się w jego umyśle ze sprawą cioci Meli, bohater w ogóle nie wspomina o jej kryminalnym tle. Drastyczne okoliczności śmierci cioci Meli, w tak sugestywny sposób wykreowane w tekście wcześniej, zastępuje teraz motyw choroby, pobyt w więzieniu - sprawy spadkowe. Kiełkuje więc podejrzenie, że zbrodni nie było. Mimo to Janek sam chce coś w związku z przeszłością ustalić - jakby zbrodnia była wytworem jego umysłu, a nie faktem stwierdzonym przez sędziego Uxakowskiego. Kolejne

nowią przyczynę niechęci krytyków w stosunku do tego, jak się wydaje, niedocenionego autora. To, co przez literaturoznawców zostało uznane za „niekonsekwencję i błąd konstrukcyjny” (WysŁouch 1977: 154), powinno jednak zostać odczytane jako „udziwnienie" w rozumieniu Wiktora Szkłowskiego, umożliwiające nowe spojrzenie na kryjące się pod podszewką powieści kryminalnej aspekty.

10 Taki sposób opowiadania zasugerowany jest w powieści wewnętrznie: Janek wspomina bowiem, że jego narracją kieruje ciocia Idalka Ryłłowa, opowiadająca wszystko (czy też kłamiąca) po kobiecemu - z dużą ilością szczegółów. 
wydarzenia ten niepokój informacyjny potwierdzają: gniazdko, które było w błękitnym pokoju nowe i stanowiło dowód obecności obcych (szpiegów?), jest znowu stare i brązowe, dziurka od klucza, rzekomo naoliwiona, okazuje się zakurzona i zardzewiała (por. KB 438-439) świadczy to o zacieraniu śladów czy stanowi dowód na nieprawdziwość zdarzeń opisywanych dotychczas na ponad czterystu stronach powieści? Motyw choroby cioci występuje również w rozmowie Janka z Wileńskim oraz szatniarzem z restauracji Pod Ratuszem. Abyśmy nie mogli jednak wierzyć szatniarzowi, opowiada on też o śmierci Pawlickiej, którą Janek, wedle swej relacji, niedawno spotkał. Czy szatniarz myli fakty, czy Janek ma przywidzenia? Jeżeli Fiłomadzki widuje duchy, to mógł również wykreować zabójstwo, którego nie było. A brak zbrodni jest oczywistym pozbawieniem powieści kryminalnej centralnego motywu - operacją analogiczną do unieważnienia podmiotu zachodniej metafizyki.

\section{Motyw kotłów}

W kontekście filozofii Jacques’a Derridy warto przyjizeć się również tytułowym kotłom oraz IX symfonii Ludwiga van Beethovena. Motywy te zachęcają do odczytania powieści jako metaforycznej partytury małomiasteczkowego życia. Jan Fiłomadzki przedstawia siostrze szarytce swoją „teorię moralną”, w której porównuje kotły do instrumentów niegrających partii solowych, pozostających więc w cieniu innych instrumentów, do szarych mieszkańców miasteczka. Użycie kotłów $\mathrm{w}$ IX symfonii w części ritmo di tre battute bez towarzyszenia innych instrumentów dowodzi, zdaniem niedoszłego pianisty, „że i w najgorszym człowieku odzywa się coś dobrego" (KB 468). Optymistyczna teza sformułowana jest $\mathrm{w}$ powieści tak jasno, że nie sposób właściwie oprzeć się pokusie wykorzystania jej w interpretacji. I tak np. Ryszard CHodźко sugeruje: „Jan Fiłomadzki [...] przy pomocy »IX Symfonii« chce uporządkować chaos rzeczywistości. Przeniknięty ideą »radości życia« neutralizuje demonizm otoczenia, wierzy, że »kotły ludzkie« można ze sobą duchowo zestroić" (1993: 136). Przesłanie Kotłów Beethovenowskich Chodźko odczytuje jako przeciwieństwo wymowy Doktora Faustusa Tomasza Manna, w którym Adrian Leverkühn marzy o symfonii zła, która byłaby w stanie zanegować optymizm IX symfonii. Podobne stanowisko zajmuje Seweryna Wysłouch: „W Kotłach Beethovenowskich kotły IX symfonii, według słów narratora, ordynarne bębny wydobywające ze siebie raz po raz szlachetny dźwięk, symbolizują dobro, które może się odezwać w każdym człowieku" (WysŁouch 1977: 29). Choromański 
prawdopodobnie przewidział taką interpretację, to pragnienie „faktów łatwo sprawdzalnych" (KB 454). Teoria Janka jednak nie sprawdza się zwykłe, ludzkie kotły, które pragnie usłyszeć, często milczą (np. mecenas Hawranek (KB 442), Rogatkowie (KB 461) lub ich udział w symfonii życia pozostaje niejasny (Wileński, Miriam, Porowski)). „Beethoven niestety był głuchy" (KB 468), a Janek ,jak każdy odkrywca [naginał K.S.P.] do swej teorii fakty" (KB 461). Moim zdaniem w Kottach Beethovenowskich istotną rolę odgrywa nie konstrukcja teorii moralnej, ale narzucona przez wewnątrzpowieściowe życie jej dekonstrukcja, potwierdzająca Derridowską niewiarę w teleologiczne twierdzenia.

Motyw kotłów przywodzi na myśl postmodernistyczne założenia także pod innymi względami:

- Kiedy w drugiej części scherza przy ritmo di tre battute timpani to znaczy kotły, proszę siostry! - zagrały motyw same, publiczność wybuchła oklaskami. Tak hucznymi, że przegłuszyły one orkiestrę. Mistrz... to znaczy Beethoven wciąż wskazywał tempo, aż Umlauf ruchem ręki nie zwrócił jego uwagi na poruszenie publiczności.

KB 444

Przyjmując, że „oklaski publiczności” symbolicznie wskazują na proces recepcji, natomiast orkiestra i Beethoven reprezentują instancję twórczą, można dopatrzyć się w tym fragmencie alegorii teoretycznoliterackiej koncepcji „śmierci autora”. Stwierdzenie, że „oklaski publiczności przegłuszyły orkiestrę", akcentuje moment, w którym odbiorcy przejmują kontrolę nad udostępnionym im przez twórcę dziełem sztuki. Odpowiada to roli, jaką przyznaje czytelnikowi w swoim manifeście Barthes. W scenie z powieści Choromańskiego „oklaski publiczności” powodują, że na sali koncertowej słychać zupełnie coś innego niż to, co stworzył autor. Są jak interpretacje, które nakładają się na dzieło (nie tylko literackie), nadając mu nowe znaczenie, a nawet niwelując intencje twórcy. Beethoven wciąż stara się wskazywać tempo, ale nie decyduje już o tym, co dzieje się z jego utworem. Jest częścią gry, którą co prawda zainicjował, ta jednak toczy się dalej niezależnie od niego. Nie ma wpływu na przebieg wydarzeń, pomimo że, jak autor w koncepcji hermeneutycznej, zajmuje pozycję w centrum:

Beethoven uplasował się w środku wykonawców. Miał przed sobą pulpit, na którym położył swój skrypt. [...] To było rozdzierające, gdy się myślało, że nie jest on zdolny do tego, by śledzić muzykę. Acz wydawało się, że śledzi ją czytając nuty - w końcu każdej części przewracał kilka stron partytury na raz. 
Proces słyszenia zostaje tu zastąpiony przez widzenie: phonos i logos ulegają wyparciu przez écriture, które zdaniem dekonstrukcjonistów z natury przyznaje się do niejasności i czyni z niej swój atut - Beethoven nie może śledzić muzyki, która wymknęła się spod jego kontroli, mimo że ma przed sobą skrypt (a więc rodzaj pisma). Écriture nie jest sposobem na odnalezienie głosu, ale potwierdzeniem jego nieobecności. Kategorie głosu i pisma dyskutowane są w Kottach Beethovenowskich częściej:

Gdybym zamiast pisać, opowiadał o tym w kółku znajomych, może byłbym potrafił intonacją głosu, odpowiednim szeptem lub akcentem sprawić to, żeby jakiś odcisk, niczym ślad na piasku, pozostał w pamięci słuchającego. Zawołałbym „rękawiczki!” i zrobił pauzę. Powiedziałbym rozciągając słowa: „za-gi-nął klu...ucz!” i popatrzyłbym znacząco. Wreszcie wzniósłszy palec rzekłbym z naciskiem: „okiennica była nie zamknięta!" Wówczas słuchający mnie moi znajomi, acz nie widząc w rękawiczkach czy też w otwartej okiennicy i zniknięciu klucza niczego godnego uwagi - po prostu mechanicznie zapamiętaliby te wypadki. Utrwalone przeze mnie fiksatywem wykrzykniku i geście, nawet wzbudziłyby w nich zaciekawienie.

Natomiast pisząc - jestem zupełnie bezradny, gdyż nie sposób zwykłym chronologicznym opisem mało ważnych drobiazgów zatrzymać czyjejkolwiek uwagi, a zwłaszcza uwagi ludzi obcych, którzy tych wydarzeń i ich zakończenia nie byli świadkami.

KB 121

Przytoczony cytat intryguje aluzją do poglądów Platona przedstawionych w Fajdrosie - pismo pomaga w przechowywaniu informacji, a zarazem ma działanie negatywne, zwalniając umysł z obowiązku rejestrowania wiadomości, ograniczając więc jego zdolność zapamiętywania. W ten sposób Platon dowodzi niedoskonałości pisma. Przekonanie to sprawia, że przyznany mu zostanie, aż do momentu wystąpienia Derridy, status drugorzędny w stosunku do mowy. Mowa oznaczała bowiem w filozofii metafizycznej obecność nadawcy, pismo - jego brak. W związku z tym pojawiła się kwestia rangi literatury, będącej przecież pismem. Wyjściem z impasu zdawało się uznanie jej za pismo jedynie $\mathrm{w}$ znaczeniu formalnym, natomiast pod względem przekazu, dotarcia do znaczenia, sugerowano uznanie jej za mowę ${ }^{11}$.

11 Przykładem takiego logocentrycznego ujęcia literatury jest filozofia Ingardena, który wysuwa „brzmienie” oraz „wyraz” jako nośnik znaczenia na plan pierwszy, pomijając pismo i druk (por. BURZYŃSKA 2006: 217). 

nie wiedząc, kto i kiedy będzie jego odbiorcą. Dzieło literackie wypuszczone z rąk twórcy, podejmuje samodzielny żywot. Autor zostaje „uśmiercony” - nie może ani użyć gestów, ani akcentów, aby zwrócić uwage czytelnika na to, co chciał powiedzieć. W ten sposób w procesie recepcji możliwe i nieuniknione są „dziury” - przeoczenie elementów przez nieuważnego czytelnika, łączenie ich w relacje niezamierzone przez autora oraz przeciwnie - zapełnianie miejsc pustych informacjami, z jakichś powodów uznanych przez czytelnika za ich dopełnienie. W procesie czytania nigdy nie mamy do czynienia z oryginałem, lecz tylko i wyłącznie z kopią, niedokładną i przybliżoną w stosunku do pierwowzoru, wykreowaną przez czytelnika. Z pojęciem écriture wiąże się więc nierozerwalnie pojęcie lecture.

Powróćmy jednak do IX symfonii. Kotły, które Janek wykorzystuje do stworzenia swej „teorii moralnej” (KB 446), występują w niej same, bez towarzyszenia innych instrumentów, tylko w drugiej części (Molto vivace), która pod względem formalnym stanowi scherzo. Powtarzają one skromny pod względem melodycznym motyw opadającej oktawy. Wykorzystanie kotłów, które dotychczas pełniły w orkiestrze wyłącznie funkcję wspomagającą, w charakterze instrumentów solowych prowadzących dialog z orkiestrą stanowi faktycznie zabieg innowacyjny. Opowieści Janka o burzy oklasków, jaką publiczność zareagowała podczas pierwszego wykonania Scherza, znajdują swoje potwierdzenie w źródłach historycznych ${ }^{13}$. Tym niemniej określając wykonywany przez kotły mo-

12 Derridowskie ujęcie kategorii mowy i pisma, a zwłaszcza wyrażona przez niego krytyka ich tradycyjnego rozumienia, podkreślane były w literaturze sekundarnej niejednokrotnie. Anna Burzyńska pisze o tym w następujący sposób: „Jak uznanie literatury za mowę przynosiło, zdaniem Derridy, złudzenie całkowicie drożnego [...] kanału sensu, treści, prawdy, a w konsekwencji niczym niezakłóconej możliwości dotarcia do poz językowych desygnatów, tak przyznanie jej statusu pisma symbolizować miało li tylko językowe lub formalne, a zarazem kreacyjne aspekty przekazu, dla wygody usuwane na margines przez metafizykę, wiedzę, teorię, przede wszystkim zaś przez tradycyjną hermeneutykę" (BuRZYŃsKa 2006: 217).

${ }_{13}$ Por. zapiski Antona Schindlera i Karla Holza w zeszytach konwersacyjnych, za pomocą których tracący słuch Beethoven porozumiewał się z otoczeniem: Beethoven (1824: skan 25 /folio 10r i 1826: skan 39 i 40 /folio 16r i 16v) oraz wykorzystaną w powieści częściowo dosłownie relację Felixa Weingartnera z jego spotkania z Heleną Grebner (WEINGARTNER 2014: 1-5). 
tyw (złożony z zaledwie dwóch dźwięków) jako melodię, bohater obciąża je nadmiarem znaczenia. Mówiąc o kotłach, Fiłomadzki uruchamia również mechanizm błędu, podobny do Derridowskiej différance ${ }^{14}$ : instrumenty te w drugiej części IX symfonii, do której bohater powieści się odwołuje, miejscu, oznaczonym w partyturze wskazówką metryczną ritmo di tre battute, nie grają bowiem „re”, a później dwóch innych „re” z rzędu (KB 49), jak twierdzi Janek, lecz dźwięk „fa” w oktawie małej i wielkiej. Kotły, które pretendują do roli przewodniego motywu w powieści, sa pomyłką. Teorii moralnej Janka brakuje zatem podstawy. Zamiana „fa” na „re” oczywiście (w przeciwieństwie do błędu graficznego Derridy, który w słowie différance zamiast „e” stosuje „a”) w przypadku wykonywania utworu muzycznego byłaby słyszalna, dotyczy nie tylko zapisu, ale też muzycznej mowy. Zastosowana w powieści jest jednak błędem bardzo subtelnym i z tego względu prawie niezauważalnym. Janek, opisując motyw kotłów, podaje wiele szczegółów, które odpowiadają muzycznej rzeczywistości: prawdziwa jest IX symfonia, prawdziwe jest $\mathrm{w}$ niej miejsce sprecyzowane przez wskazówkę ritmo di tre battute. Faktycznie kotły grają tam same. Zgadza się również trzykrotne powtórzenie przez nie tego samego dźwięku, tekst Choromańskiego imituje nawet właściwości rytmiczne wspomnianego motywu ${ }^{15}$. Poza tym „re”, czyli (posługując się częściej stosowanymi nazwami literowymi dźwięków) „d” w symfonii d-moll, stanowi tonikę, użycie tego dźwięku w partii kotłów jest więc bardzo prawdopodobne, a na dodatek prawdziwe w części pierwszej i czwartej utworu. Mamy zatem do czynienia $\mathrm{z}$ wieloma poprawnymi elementami i jednym błędem - operacją porównywalną do powstania neologizmu différance. Kotły, przywołane w tytule powieści i stanowiące motyw przewodni utworu, pełnią w nim funkcję podobną do tej, jaką Derrida przypisuje różni: podporządkowują go „nieporządkowi, który się w nim wytwarza” (DERRIDA 1978: 376).

\section{Błędne tropy - kolory i watki intertekstualne}

Powieść Choromańskiego pełna jest znaków o niezwykłym stężeniu semantycznym, mają one funkcję wskaźników, które sugerując nie-

${ }^{14}$ Derridowska différance pojawia się w Kotłach Beethovenowskich również w grze nazw własnych: ciocia Mela, z domu Brzewuska, zachowuje się jakby pochodziła z Rzewuskich (KB 163), IX symfonia to symfonia d-moll, Janka prześladują de-mony (KB 68), Marysia nazywała się Falc, ale jej nazwisko przekręcano na Walc (KB 40).

15 Por. zapis „tom! tom-tom!” (KB 49) i „Tom... tomtom!” (KB 450), w którym wykrzyknik i wielokropek mogą być traktowane jako ekwiwalent dłuższej wartości rytmicznej (ćwierćnuty z kropką i ćwierćnuty w partyturze). 
zliczoną liczbę możliwości, sprawiają, że nieuchronnie gubimy trop ${ }^{16}$. $\mathrm{Na}$ uwagę zasługuje np. symbolika kolorów, którą warto prześledzić na przykładzie czerwieni i błękitu (oczywiście nie wyczerpuje to tematu, ponieważ w Kotłach Beethovenowskich pojawia się też motyw czerni oraz światła, które zamiast oświetlać często razi, uniemożliwiając postrzeganie $\left.{ }^{17}\right)$. W powieści kolor czerwony pojawia się już $\mathrm{W}$,anteludium" (KB 367) w cytowanym wcześniej fragmencie dotyczącym znalezienia cioci Meli. Tak wprowadzony do akcji kolor czerwony łączy się więc ze śmiercią, zbrodnią i winą. W chwili złośliwości w stosunku do siostrzeńca, którego charakter i styl życia nie cieszy się jej aprobatą, ciocia Mela trzyma w ręku „czajnik, co przykryty był odziankiem szydełkowej roboty z czerwonej wełny" (KB 90) ${ }^{18}$. Szton czyta oprawione w czerwone płótno sprawozdanie z procesu Oscara Wilde'a. Oficer towarzyszący sędziemu podczas przesłuchania Janka w wieczór zabójstwa, ma na ramieniu „dwie naszywki oraz bardzo czerwony zygzak" (KB 78 i 79). W podejrzany krąg czerwieni wpisana zostaje także Pawlicka, powiernica swojej pani i wróg Janka, której ręce w nocy, kiedy dokonano rzekomego zabójstwa, „purpurowiały”19. Kulminacja czerwieni następuje w chwili wizyty sędziego Uxakowskiego u fotografa Grubowolskiego, obaj mężczyźni oraz pani Grubowolska zdają się krwawić, skąpani w czerwonym świetle (por. KB 303-306). Po tej sce-

${ }^{16} \mathrm{Na}$ arbitralność znaków używanych przez Choromańskiego wskazuje m.in. R. CноDźко: „Znaki językowe stają się ważnym - by tak rzec - elementem życia. W większości wyrażeń używanych przez bohaterów Choromańskiego więź między elementem znaczącym i elementem znaczonym jest »dowolna «, ponieważ autor podkreśla dymorficzne oblicze przedstawionych zjawisk i aktów mowy - i ten paradoksalny fakt, że z jednej strony język »przesłania myśl « (służy »nieświadomości«), a z drugiej jest »narzędziem poznania«" (1993: 127).

17 Światło przywodzi zatem na myśl Platoński i Derridowski pharmakon, który jest zarazem lekarstwem i trucizną.

18 Złośliwość cioci polega na stosunkowo błahym fakcie, że prosi ona siostrzeńca o przyniesienie do jadalni gorącego rondla z gołąbkami. Stanowi on zagrożenie dla delikatnych rąk pianisty, który dość bezmyślnie chwyta za rozgrzaną rączkę. W odniesieniu do powieściowego systemu znaków ciekawe jest to, że rondel ma rączkę o kolorze błękitnym, a kolor ten odgrywa również istotna rolę w powieści.

19 Poza tym Pawlicka „nie mogła domyć swych talerzy - wszystkie bowiem pokryte były czymś czarnym, rodzajem sadzy!" (KB 425) - w tym fragmencie zwraca uwage podejrzany kolor czarny, który pojawia się także w innych miejscach przełomowych dla akcji. Wojskowy, który uczestniczy w przesłuchaniu Janka, wpatruje się w niego „nasępionym, czarnym (okropnym) wzrokiem" (KB 369). Czarny jest tego wieczoru również atrybutem sędziego Uxakowskiego - „kiedy w pewnych momentach oczy jego i twarz stawały się czarne i pełne nienawiści, nie mogłem pojąć, dlaczego wyczuwam w nim Zło, a zatem niemoralność. [...] W czarnych źrenicach - że znowu użyję przymiotnika »czarny«. Nie daremnie jednak w języku naszym słowo »czarność« znaczy nieraz to samo co »złe przywary«" (KB 369). 
nie czytelnik skłonny jest widzieć w sędzim i Grubowolskim głównych podejrzanych. Radość z uchwyconego tropu psuje niestety fakt, że w powieści czerwienią się wszyscy - nikt nie jest wolny od winy, choćby stwarzał wcześniej wrażenie niewinności - czerwieni się, nie wiadomo czemu, Klara Doleżał (por. np. KB 24), czerwień „prześwieca [...] spoza szczeciny Porowskiego" (KB 466). Purpurowym rumieńcem oblewa się twarz adwokata Hawranka (por. KB 441). Nawet wzbudzający sympatię lekarz Marcinkiewicz naznaczony zostaje czerwoną skazą: ma „perkaty [...] czerwony [...] nos [...]" (KB 34) i pisze swe aforyzmy w czerwonym, safianowym zeszycie (por. np. KB 28).

Ponurym znakiem jest $\mathrm{w}$ powieści również kolor błękitny. Ludomir Sebastian Szton nosi kurtkę „koloru bleu électrique” (KB 12). Na nosie Klary Doleżał „niebieskie pince-nez błys[ka] takim niepokojem, prawie rozpaczą..." (KB 73). Niebieska jest także waza, przywieziona przez Sztona do miasteczka razem z figurką św. Sebastiana (por. KB 73), waza, która może być znakiem dla szpiegów czy też przemytników. Zostaje ona uznana przez sędziego za jeden $\mathrm{z}$ dowodów przeciwko Jankowi, który dostaje ją od Sztona w prezencie urodzinowym. Błękit spowija pokój Eriki Natowskiej, która szantażuje Fiłomadzkiego, domagając się od niego dostarczenia trucizny, podobno, aby odebrać sobie życie i skrócić cierpienia - podobno - bo od trucizny pada Baca, pies Grubowolskiego, a pani Natowska umiera - jak wiadomo - „nieszczerze” (KB 342), z powodu miażdżycy.

Uwodząca miejscowych chłopców wdowa po staroście - Marysia, zostaje określona przez Sztona jako „Sinobroda”20, co jest oczywiście intertekstualnym nawiązaniem do literackiego motywu Sinobrodego ${ }^{21}$. Broda o niezwykłym kolorze stanowi symbol wewnętrznego zepsucia

${ }^{20}$ Kolor niebieski w słowie „Sinobrody” wyraźnie widoczny jest w tłumaczeniach na inne języki, np. niemiecki - Blaubart, francuski - Barbe-bleu, angielski - Bluebeard.

${ }^{21}$ Postać Blaubarta otwiera różne wątki intertekstualne. Jest on bohaterem wielu utworów literackich: np. dramatu L. Tiecka Ritter Blaubart. Ein Ammenmärchen in vier Akten, który ukazał się najpierw w roku 1797 w pierwszej części wydanych przez Petera Leberechta Volksmährchen i w roku 1812 jako Der Blaubart. Drama in fünf Akten w zbiorze Phantasus (1812) oraz opowiadań: Alfreda Döblina Blaubart und Miß Ilsebill (1911), Maxa Frischa Blaubart (1982), Petera Rühmkorfa Blaubarts letzte Reise (1983). Szczególną popularnością cieszył się Blaubart w literaturze XX wieku. Jest on również bohaterem opery buffa Barbe Bleu Jacques'a Offenbacha (1866) oraz powstałej na podstawie sztuki Maurice'a Maeterlincka opery Paula Dukasa Ariane et Barbe-Bleue (1907). Za wątek hipertekstualny uznać należy również pewne motywy występujące w opowieściach o Sinobrodym i przejęte w Kottach Beethovenowskich: pokój, do którego nie wolno wchodzić; klucz, który ginie i ma się znaleźć; strach i kłamstwa dziewczyny, która chce ukryć brak klucza i pragnienie Janka, aby klucz się pojawił jako dowód jego niewinności. 
oraz demoniczności. Za historyczny pierwowzór Sinobrodego uznawany jest Gillies de Rais, o którym wspomina w Kottach Beethovenowskich sam Szton (por. KB 172). Kolor niebieski prowadzi zatem do śladu seryjnego piętnastowiecznego mordercy z XV wieku, który zabił na tle seksualnym setki młodych chłopców i dziewcząt. Gilles de Rais zajmował się okultyzmem i poświęcał swoje ofiary demonowi o imieniu „Barron”, obiecując sobie w ten sposób przywrócenie roztrwonionego wcześniej majątku. Postać sinobrodej Marysi może zatem zostać odczytana jako złowrogi demon, składający baronowi Sztonowi młodego Janka w ofierze. Tu jednak trop ten się urywa, pozostaje jedynie możliwością, równie prawdopodobną jak wiele innych przedstawionych $\mathrm{w}$ powieści.

Z łańcuchem zła kojarzy się w Kotłach Beethovenowskich również przymiotnik „mokry”. Dom zamordowanej cioci stoi nad stawem, za którym biegnie pas graniczny, od strony wody miga w nocy tajemnicze światełko. W wieczór zabójstwa jest „duszno, ciepło i wilgotno” (KB 7-8). Grubowolski mówi „soczystym mokrym basem pięćdziesięcioletniego mężczyzny" (KB 6), gdy Janek przybiega do niego po pomoc, fotograf krzyczy „basem, jeszcze mokrzejszym” (KB 7). Zanim Baca zostanie otruty, rozlega się jego „mokre ujadanie” (KB 145). Wodne porównanie służy do opisu Sztona, który przypomina akwarelę „na wyżółkłym papierze, do której kiedyś więcej użyto wody niż farby" (KB 13). Kiedy w pobliżu domu cioci Meli Janek Fiłomadzki zauważa podejrzanych, żywo gestykulujących rowerzystów, zdających się mieć coś wspólnego $\mathrm{z}$ sugerowanym $\mathrm{w}$ powieści wątkiem szpiegowskim, pada deszcz, a ziemia zamienia się w mokradło (por. KB 208-209).

Metaforyka wodna prowadzi intertekstualnym tropem do określanego w literaturoznawstwie niemieckim jako „manifest wczesnego romantyzmu” (ALEWYN 1944: 48) zbioru Wynurzenia serdeczne rozmiłowanego $w$ sztuce braciszka zakonnego (Herzensergießungen eines kunstliebenden Klosterbruders), a w szczególności do zamieszczonego w nim opowiadania Widzenie Rafaela Wilhelma Heinricha Wackenrodera ${ }^{22}$. Na potwierdzenie tej tezy przywołajmy wypowiedź Ludomira Sztona:

Pragnąłem udowodnić, że w rysach Madonny chrześcijańskiej odnaleźć można podobieństwo do rysów pogańskiej Wenery... W Toscanie, „gdzie lud się wciąż schylat przed Krzyżami, lecz gdzie dawniejsi bogowie powstali już z prochów" [...], to krewieństwo rysów było czymś niezbitym! Oblicze Madonny i Venus zlały się podtenczas w całość,

22 Wynurzenia serdeczne... ukazały się anonimowo, wiadomo jednak, że są one owocem współpracy Wilhelma Heinricha Wackenrodera i Ludwiga Tiecka. Trudna kwestia autorstwa poszczególnych części zbioru została wyjaśniona w artykule Richarda Alewyna (por. Alewyn 1944: 48-58). 
Aufsätze/Artykuły

iluminującą ową dobę. Dobę Quattrocento. Lecz ja podejrzewam skądinąd, że już w Bizancjum to się zaczęło i że wielkie umęczone oczy znane nam z mozaik są oczami przerażonej bogini miłości, która powstała z piany morskiej. Ujrzała Krzyż i przelękła się...

KB 182-183

Podobny proces - przejście od nimfy morskiej do Madonny - rozgrywa się właśnie w Widzeniu Rafaela, stając się punktem wyjścia szeregu innych zabiegów substytucyjnych. Wackenroder opowiada fikcyjną historię o cudownym widzeniu Rafaela. Madonna, która objawiła się artyście, miała mu posłużyć za wzór, który naśladował w swych licznych obrazach Matki Boskiej. Fikcjonalny Rafael podkreśla wartość swej wewnętrznej inspiracji słowami: „Ponieważ widuje się tak niewiele pięknych postaci niewieścich, dlatego kieruję się w swym wnętrzu pewnym obrazem, który spływa do mej duszy“ (Wackenroder 2000: 7). Zdanie to jest lekko zmienioną wersją wypowiedzi historycznego Rafaela, która zachowała się w liście malarza do hrabiego Castiglione. W dokumencie tym jednak postać, która rzekomo ukazała się artyście, to nie Madonna, ale Galatea - nimfa morska. Wizerunki Madonny w opowiadaniu Wackenrodera są zatem kopią pogańskiej boginki. W literaturze badawczej tę substytucję postaci tłumaczy się jako alegorię przejścia od estetyki antycznej do średniowieczno-chrześcijańskiej (por. LubKoll 1995: 127-129).

Między Widzeniem Rafaela a Kotłami Beethovenowskimi zachodzi jednak dość znamienna różnica: podczas gdy u Wackenrodera obserwujemy przejście od Galatei do Madonny - Madonna z jego opowiadania przykrywa Galateę z listu Rafaela - u Choromańskiego proces ten przebiega odwrotnie: od Madonny do Galatei/Wenery („,Pragnąłem udowodnić, że w rysach Madonny chrześcijańskiej odnaleźć można podobieństwo do rysów pogańskiej Wenery...”; KB 182-183) - Szton odkrywa w obrazie Madonny cechy pogańskiej bogini. Wackenroder unaocznia zatem stabilizację estetyki chrześcijańskiej, a co za tym idzie, związanego z nią sposobu tłumaczenia świata, Choromański wskazuje na to, że w chrześcijańskiej metanarracji obecne są ślady poprzednich wielkich opowiadań, które tylko pozornie zostały przez nią wyparte ${ }^{23}$.

Warto wspomnieć o jeszcze jednym intertekstualnym śladzie prowadzacym od Kottów Beethovenowskich do Osobliwego żywota muzycznego kompozytora Józefa Berglingera $w$ dwóch częściach głównych, jednego z naj-

${ }^{23}$ Efekty nakładania się wzorców Madonny i Galatei stają się ponadto w Kottach Beethovenowskich źródłem napięć w kobiecych postaciach: sinobroda Maria Falc jest „mam[ą] kochając[ą] gimnazjalistów” (KB 46), a obłąkana prostytutka Safo powtarza imię Miriam, będące hebrajskim odpowiednikiem Marii (KB 257). 
ważniejszych opowiadań zbioru Wynurzenia serdeczne... Bohaterowie obydwu utworów mają wiele wspólnego: Joseph jest półsierotą, Janek sierotą (obydwa życiorysy naznaczone są zatem piętnem nieobecności rodziców). Obydwaj są muzykalni i duszą się w drobnomieszczańskiej atmosferze. Berglingerowi na drodze do muzyki staje ojciec, Jankowi ciotka, która nie wykazuje zrozumienia dla jego sztuki. Porównanie życiorysów Josepha i Janka uwypukla kolejne puste miejsce w Kotłach Beethovenowskich - podczas gdy Berglinger zostaje muzykiem, Janek muzykiem nie będzie - jego muzykowanie okazuje się „blagą” (KB 392).

\section{Narracja jako gra z czytelnikiem}

Narracja powieści skonstruowana jest tak, aby siać niepewność. Nieporozumienie staje się podstawą obranej przez autora strategii komunikacyjnej (por. LEOciak 1982). Tekst w autoreferencyjny sposób podkreśla sprzeczności związane z relacjonowaniem wydarzeń i wynikający z tego dla całej powieści imperatyw nielogiczności. Manifestująca się miejscami w narracji polifoniczność sugeruje jej nieścisłość. I tak, np. w opowiadaniu o przybyciu Sztona do miasteczka można wyróżnić trzy głosy. Wydarzenie to opisuje w rozmowie z Jankiem malarka Klara Doleżał, która nie była jednak jego świadkiem i dowiedziała się o nim od nauczycielki muzyki, pani Kurdesz. Trzeci głos należy do Janka, który jako narrator autodiegetyczny odtwarza w powieści swoją rozmowę z Klarą. Uwaga o talencie narratorskim pani Kurdesz (por. KB 30) podkreśla możliwą rozbieżność między rzeczywistym przebiegiem wydarzeń, a ich rekonstrukcją w jej wypowiedzi.

Wątpliwości powstające u czytelnika wskutek nagromadzenia sprzecznych faktów w powieści potęgowane są przez postawę narratora, ukształtowanego wyraźnie jako narrator niewiarygodny ${ }^{24}$, któremu nie można ufać. Janek Fiłomadzki sam zauważa, że boi się coś przekręcić (por. KB 34). Zaznacza, że jego relacja jest subiektywna i że opis wydarzeń dzieli od nich przestrzeń czasowa, co powoduje duże prawdopodobieństwo zniekształcenia ich przebiegu w pamięci bohatera ${ }^{25}$. Narrator sam wskazuje na elementy, które, w jego opowiadaniu, zostały pomi-

${ }^{24}$ Termin ten został wprowadzony do teorii literatury przez Wayne'a C. BоoтHA (1961: 211). Wolfgang Iser podkreśla rolę narratora niespolegliwego w akcie komunikacji literackiej. Jego zdaniem ten typ narratora „odpowiada pewnemu strategicznemu zamysłowi, odnoszącemu się do sterowania czytelnikiem przez tekst" (Iser 1980: 270), co znajduje potwierdzenie w Kotłach Beethowenowskich.

${ }^{25}$ Por. następującą uwagę narratora: „Zdawać by się mogło, a piszę to z odległości lat..." (KB 369). 
nięte (a więc na to, co w tekście - jak powiedziałby Derrida - nienapisane $)^{26}$. Jednocześnie Janek kilkakrotnie przekonuje czytelnika o prawdziwości swych słów ${ }^{27}$. Na przekór swym zapewnieniom o szczerości daje jednak w innym miejscu do zrozumienia, że wersja opowiedziana przez niego sędziemu mija się z prawdą i została odpowiednio ubarwiona kłamstwami, szeptanymi mu przez ciocię Idalkę Ryłłową ${ }^{28}$. Zamiast zmierzać do rozwiązania, narrator pod koniec powieści otwarcie przyznaje się do umyślnego gmatwania faktów, prowadzi z czytelnikiem coraz bardziej przekorną grę ${ }^{29}$ :

Nie wiem... nie pamiętam, i... w ogóle może nic nigdy nie było! Może miasteczko, które opisałem, wcale tak nie wyglądało i to ja, całkiem świadomie, by nie wywoływać duchów w niedobrą godzinę, zmieniłem topografię; [...] Nie wiem. Już właściwie nic nie pamiętam. A czy ja w ogóle coś przedtem mówiłem?

$\mathrm{KB} 428^{30}$

Czytelnik zostaje w ten sposób niejako zmuszony do przyjęcia dekonstruktywistycznej postawy wobec powieści Choromańskiego. Każda próba jednoznacznej interpretacji kończy się - z powodu mnogości rzucanych przez tekst śladów - niepowodzeniem. Kotty Beethovenowskie zadają pytania, ale nie udzielają odpowiedzi. Sieją niepokój, pozwalając odbiorcy otrzeć się o formę prawdy, ukrywając jednocześnie skrzętnie

${ }^{26}$ Ilustruje to np. fragment: „Nie streściłem zbyt ściśle wszystkich rozmów, jakie prowadziłem z generałem-poetą; wiele opuściłem - wybrałem to tylko, co wydawało mi się najważniejsze" (KB 363).

27 Por. np. KB 11, 202, 357.

${ }^{28}$ Zafałszowanie prawdy jako działanie celowe i niewynikające z ułomności ludzkiej pamięci to motyw, który w Kotłach Beethovenowskich kilkakrotnie się powtarza. Narrator określa swój sposób relacjonowania jako technikę wariacyjną, por. na ten temat KB 379, 389, 396.

${ }_{29}$ Taka praktyka odpowiada zwrotowi narracyjnemu w teorii literatury, który w okresie postmodernistycznym robił zawrotną karierę i którego głównym wyznacznikiem było przełożenie środka ciężkości z pytania „co przedstawia dzieło literackie?” na pytanie: „jak ono przedstawia?”. Por. na ten temat wypowiedź D. CARrola: „W sposób podobny do teorii aktów mowy pragmatyka narracji przenosi bowiem punkt ciężkości z prawdy narracji, to znaczy z prawdziwości tego, co przedstawia na siłę opowiadania, jego dramatyczne bądź performatywne efekty" (1991: 57). Na charakterystyczny dla Choromańskiego sposób narracji, polegający na zwodzeniu czytelnika, zwraca uwagę również Seweryna Wysłouch, określając go trafnie mianem „zasady zawiedzionego zaufania”, która w okresie powojennym „staje się dominantą strukturalną” powieści tego autora (WysŁouch 1977: 80). S. Wysłouch traktuje taką technikę narracyjną jako negację konwencji powieści klasycznej.

${ }^{30}$ Podobne wzmianki dotyczące wątpliwości co do prawdziwości własnej relacji wyrażone są jeszcze kilkakrotnie, co podkreśla ich ważność, np. KB 435, 436, 458. 
- No i jak się to skończyło?

- Na tym właśnie cała rzecz polega, że nie było żadnego zakończenia, żadnej pointy - odrzekł [Szton - K.S.P.].

- Jak to?

- Ano, po prostu do dziś dnia nie wiem, jak to wytłumaczyć. Widziałem wiele rzeczy dziwnych w życiu, ale wyznam, że żadna jak dotąd tak mnie nie zdziwiła... Nielogiczność! nielogiczność zawsze oszałamia... to straszna siła, to straszne torrturry, nie móc czego zrrozumieć...!

KB 135-136

\section{Literatura}

AlEWyn Richard (1944): Wackenroders Anteil. In: The Germanic Review 19: 48-58.

Bоотн Wayne Clayson (1961): The Rhetoric of Fiction. Chicago: University of Chicago Press.

Burzyńska Anna (2006): Anty-teoria literatury. Kraków: Universitas.

Carroll David (1991): Reguły gry. Tłum. Grzegorz Dziamski. W: Zeidler-Janiszewska Anna (red.): Postmodernizm $w$ perspektywie filozoficzno-kulturowej. Warszawa: Wydawnictwo Instytut Kultury: 53-63.

CHodźко Ryszard (1993): Konfesja podmiotowa w polskiej prozie kreacyjnej. Białystok: Dział Wydawnictw Uniwersytetu Warszawskiego. Filia.

Choromański Michał (1970): Kotty Beethovenowskie. Poznań: Wydawnictwo Poznańskie.

Culler Jonathan (1997): Literary Theory. A Very Short Introduction. Oxford: Oxford University Press.

Derrida Jacques (1978): Różnia (différance). Tłum. Joanna Skoczylas. W: SiemeK Marek (red.): Drogi współczesnej filozofii. Warszawa: Czytelnik: 374-411.

Derrida Jacques (1997): Pozycje. Rozmowy z Henri Ronsem, Julia Kristeva, Jean-Louis Houdebinem $i$ Guy Scarpetta. Tłum. Adam Dziadek, Bytom: Kwartalnik Literacki FA-art.

Eco Umberto/RorTy Richard/Culler Jonathan/Brooke-Rose Christine (1996): Interpretacja i nadinterpretacja. Red. Stefan Collini. Tłum. Tomasz Bieroń. Kraków: Znak. 
IsER Wolfgang (1980): Apelatywna struktura tekstów. W: Pamiętnik Literacki 71, z. 1-2: 259-280.

LeOCIAK Jacek (1982): Aranżowanie nieporozumień jako strategia komunikacyjna na przykładzie „Kotłów Beethovenowskich” Choromańskiego. W: Pamiętnik Literacki 73, z. 1-4: 213-236.

LubKoll Christine (1995): Mythos Musik. Poetische Entwürfe des Musikalischen in der Literatur um 1800. Freiburg im Breisgau: Rombach.

TiecK Ludwig (1818): Der Ritter Blaubart. Ein Mährchen in fünf Acten. In: Ludwig Tieck's Sämmtliche Werke. Bd. 12. Wien: Leopold Grund: 11-156.

WACKENRODER Wilhelm Heinrich (2000): Wynurzenia serdeczne rozmitowanego $w$ sztuce braciszka zakonnego. W: Pisma teoretyczne niemieckich romantyków. Wybrał i oprac. Tadeusz Namowicz. Tłum. Jacek S. Buras. Wrocław, Warszawa, Kraków: Zakład Narodowy im. Ossolińskich - Wydawnictwo: $5-53$.

Weingartner Felix (2014): Akkorde. Gesammelte Aufsätze. Hamburg: Severus. WoźNIAKIEWICZ-DzIADosz Maria (1979): Kategorie muzyczne w strukturze tekstu narracyjnego: na przykładzie „Kottów Beethovenowskich” Choromańskiego i „Martwej pasieki” Iwaszkiewicza. W: Pamiętnik Literacki 70, z. 4: 191-212. WysŁouch Seweryna (1977): Proza Michała Choromańskiego. Wrocław: Zakład Narodowy im. Ossolińskich.

\section{Źródła archiwalne}

Beethoven Ludwig van: Konversationsheft 66. 6.-8. Mai 1824. https://digital. staatsbibliothek-berlin.de/werkansicht?PPN=PPN1025157648\&PHYSID= PHYS_0025\&DMDID=DMDLOG_0001

Beethoven Ludwig van: Konversationsheft 114. Juli 1826, erstes Drittel. https://di gital.staatsbibliothek-berlin.de/werkansicht?PPN=PPN1029406588\&PHY SID=PHYS_0040\&DMDID=DMDLOG_0001

\section{Kotły Beethovenowskie jako partytura braku}

Streszczenie: W powieści Kotty Beethovenowskie Michała Choromańskiego kategorią centralną jest brak. Dotyczy on nieobecnych osób, zagubionych przedmiotów, nieuchwytnego znaczenia. Tekst akcentuje go wielokrotnie w autoreferencyjny sposób, np. przez użycie w różnych kontekstach pozornie mało atrakcyjnej metafory „dziura”. Obecność i nieobecność nie stanowią tu binarnej opozycji, ale się ze sobą łączą. Kotty Beethovenowskie są zatem i nie są powieścią kryminalną, Janek jest i nie jest pianistą. Znaki prowadzą w tym tekście swobodną grę z czytelnikiem, odraczając, a nawet niwecząc możliwość dotarcia do przekonującej interpretacji. Kotty Beethovenowskie, które konstytuują w świecie przedstawionym wydarzenia i twierdzenia po to, by je następnie poddać rozbiórce, mogą służyć jako literacka ilustracja dekonstruktywizmu. 


\section{Kotły Beethovenowskie (Beethovens Pauken) als Leerstellen-Partitur}

Zusammenfassung: In Michał Choromańskis Roman Kotty Beethovenowskie (Beethovens Pauken) werden Leerstellen zu einer zentralen Kategorie erklärt. Sie manifestieren sich überall dort, wo von abwesenden Personen, verlorenen Gegenständen und ungreifbarer Bedeutung die Rede ist. Der Text betont seine Leerstellen mehrmals in einem autoreferenziellen Verfahren, z. B. durch die scheinbar unattraktive Metapher des Lochs, die in verschiedenen Kontexten gebraucht wird.

Präsenz ud Nicht-Präsenz werden hier nicht als Pole einer binären Opposition aufgefasst, sondern sind miteinander verbunden. Choromańskis Werk ist also ein Kriminalroman und gleichzeitig entzieht es sich dieser Gattungsbezeichnung. Der Hauptprotagonist Janek ist Pianist und ist es zugleich nicht. Die Zeichen treiben mit dem Leser/ der Leserin ein freies Spiel, in dem sie die Möglichkeit, an eine überzeugende Interpretation zu gelangen, ständig verzögern oder sogar verweigern. Der Roman, in dem Ereignisse und Behauptungen konstituiert werden, um gleich danach in Frage gestellt oder widerlegt zu werden, kann als fiktionale Verkörperung des Dekonstruktivismus gelten. Der vorliegende Beitrag setzt sich zum Ziel, Choromańskis Strategien, die auf die Hervorhebung der Leerstellen und Aufschiebung des Sinns ausgerichtet sind, zu verfolgen und ihre Ähnlichkeit zu Prämissen der Dekonstruktion zu veranschaulichen. Eine besondere Aufmerksamkeit kommt dem Titelmotiv der Pauken zu, deren Einsatz in Beethovens 9. Sinfonie während der Uraufführung für Aufregung sorgte. Im Roman setzt das Paukenmotiv ein Räderwerk des Fehlers in Gang, das man mit Derridas différance assoziieren kann.

Schlagwörter: Kotty Beethovenowskie, Michał Choromański, Leerstelle, Dekonstruktivismus, différance

Beethoven's Timpani as a music score of absence

Summary: In his novel entitled Beethoven's Timpani, Michał Choromański made absence central category. It refers to absent persons, lost items and belongings, and the elusiveness of meaning. The narrative underscores the said category many a time in a self-referential manner, for instance, by using in various contexts a seemingly unattractive metaphor - "the hole." Presence and absence in Choromański's novel are not oppose in a binary fashion, but they interpenetrate. Beethoven's Timpani is, therefore, both a crime novel and not quite, the protagonist Janek is and is not a pianist. The traces in the text elude the reader freely, by postponing or even nullifying the possibility of attaining a convincing interpretation. Beethoven's Timpani, in whose de- 
picted world events and claims are presented only to be subsequently dismantled, may serve as an exemplification of deconstructionism in literature. The present article's aim is an inquiry into Choromański's efforts to underscore the category of absence and the meaning postponement, and pointing to those efforts' similarity to some of deconstructionist tenets. What deserve an utmost attention is the eponymous motif of Beethoven's timpani (otherwise deserves kettledrums), which in the novel triggers the error/mistake mechanism akin to Derridean différance.

Keywords: Kotty Beethovenowskie (Beethoven's Timpani), Michał Choromański, the category of absence, decosntructionism, différance

Katarzyna Szczerbowska-Prusevicius studiowała na Wydziale Instrumentalnym Akademii Muzycznej w Kolonii (Musikhochschule Köln) oraz filologię germańską w Akademii Bydgoskiej im. Kazimierza Wielkiego (obecnie Uniwersytet Kazimierza Wielkiego). W 2005 roku uzyskała tytuł doktora nauk humanistycznych. Od roku 2006 jest adiunktem w Katedrze Filologii Germańskiej Uniwersytetu Mikołaja Kopernika w Toruniu. Jej zainteresowania badawcze dotyczą związków literatury z muzyką oraz historii literatury i kultury Prus Królewskich. Obecnie pracuje nad rozprawą habilitacyjną, która poświęcona będzie literackim portretom Wolfganga Amadeusza Mozarta.

Dr. phil. Katarzyna Szczerbowska-Prusevicius studierte Instrumentalmusik an der Musikhochschule Köln und Germanistik an der Akademia Bydgoska im. Kazimierza Wielkiego (heute: Uniwersytet Kazimierza Wielkiego). Seit 2006 ist sie wissenschaftliche Mitarbeiterin am Lehrstuhl für Germanistik der Nikolaus-Kopernikus-Universität in Toruń. Zu ihren Forschungsschwerpunkten gehören Untersuchungen zu den Wechselbeziehungen zwischen Literatur und Musik sowie Kultur- und insbesondere Literaturgeschichte des ehemaligen königlich-preußischen Raumes. Zur Zeit arbeitet sie an einer Habilitationsschrift, die fiktionalen Komponistenbiographien gewidmet ist. 